Supplement of

\title{
Characterization of a real-time tracer for isoprene epoxydiols-derived sec- ondary organic aerosol (IEPOX-SOA) from aerosol mass spectrometer measurements
}

\author{
W. W. Hu et al. \\ Correspondence to: J. L. Jimenez (jose.jimenez@ colorado.edu)
}

The copyright of individual parts of the supplement might differ from the CC-BY 3.0 licence. 
Table S1. Pearson's correlation coefficients (R) between time series of organic ions and the PMF IEPOX-SOA factor for the SOAS study (SE US forest).

\begin{tabular}{|c|c|c|}
\hline Ion Formula & Ion mass & Correlation coefficient $(\mathrm{R})$ \\
\hline \multicolumn{3}{|c|}{ Ions with $\mathrm{R}>0.8$} \\
\hline $\mathrm{C}_{5} \mathrm{H}_{6} \mathrm{O}^{+}$ & 82.0419 & 0.97 \\
\hline $\mathrm{C}_{5} \mathrm{H}_{5} \mathrm{O}^{+}$ & 81.034 & 0.95 \\
\hline $\mathrm{C}_{4} \mathrm{H}_{5}^{+}$ & 53.0391 & 0.90 \\
\hline $\mathrm{C}_{4} \mathrm{H}_{6} \mathrm{O}^{+}$ & 70.0419 & 0.88 \\
\hline $\mathrm{C}_{3} \mathrm{H}_{7} \mathrm{O}_{2}^{+}$ & 75.0446 & 0.87 \\
\hline $\mathrm{C}_{3} \mathrm{H}_{5} \mathrm{O}^{+}$ & 57.034 & 0.84 \\
\hline $\mathrm{C}_{4} \mathrm{H}_{6}{ }^{+}$ & 54.047 & 0.84 \\
\hline $\mathrm{CH}_{3} \mathrm{O}^{+}$ & 31.0184 & 0.83 \\
\hline $\mathrm{C}_{4} \mathrm{H}_{7} \mathrm{O}_{2}^{+}$ & 87.0446 & 0.83 \\
\hline $\mathrm{C}_{3} \mathrm{H}_{6}^{+}$ & 42.047 & 0.82 \\
\hline $\mathrm{C}_{4} \mathrm{H}_{2}{ }^{+}$ & 50.0157 & 0.82 \\
\hline $\mathrm{C}_{5} \mathrm{H}_{8} \mathrm{O}^{+}$ & 84.0575 & 0.82 \\
\hline $\mathrm{C}_{4} \mathrm{H}_{5} \mathrm{O}^{+}$ & 69.034 & 0.82 \\
\hline $\mathrm{C}_{4} \mathrm{H}^{+}$ & 49.0078 & 0.82 \\
\hline $\mathrm{C}_{3} \mathrm{H}_{3}{ }^{+}$ & 39.0235 & 0.82 \\
\hline $\mathrm{C}_{2} \mathrm{H}_{3}{ }^{+}$ & 27.0235 & 0.81 \\
\hline $\mathrm{C}_{3} \mathrm{H}^{+}$ & 37.0078 & 0.80 \\
\hline $\mathrm{C}_{2} \mathrm{H}_{5}^{+}$ & 29.0391 & 0.80 \\
\hline $\mathrm{C}_{4} \mathrm{H}_{3}{ }^{+}$ & 51.0235 & 0.80 \\
\hline $\mathrm{C}_{3} \mathrm{H}_{2}^{+}$ & 38.0157 & 0.80 \\
\hline $\mathrm{C}_{3} \mathrm{H}_{5}^{+}$ & 41.0391 & 0.80 \\
\hline $\mathrm{CH}_{2} \mathrm{O}^{+}$ & 30.0106 & 0.80 \\
\hline \multicolumn{3}{|c|}{ Ions with lowest $\mathrm{R}$} \\
\hline $\mathrm{CHNO}^{+}$ & 43.0058 & -0.37 \\
\hline $\mathrm{CNO}^{+}$ & 41.998 & -0.12 \\
\hline $\mathrm{CN}^{+}$ & 26.0031 & -0.11 \\
\hline \multicolumn{3}{|c|}{ Other common used ions in AMS } \\
\hline $\mathrm{C}_{2} \mathrm{H}_{3} \mathrm{O}^{+}$ & 43.0184 & 0.72 \\
\hline $\mathrm{C}_{3} \mathrm{H}_{7}^{+}$ & 43.0548 & 0.57 \\
\hline $\mathrm{CO}_{2}^{+}$ & 43.9898 & 0.66 \\
\hline $\mathrm{C}_{3} \mathrm{H}_{3} \mathrm{O}^{+}$ & 55.0184 & 0.72 \\
\hline $\mathrm{C}_{4} \mathrm{H}_{7}^{+}$ & 55.0548 & 0.68 \\
\hline $\mathrm{C}_{2} \mathrm{H}_{4} \mathrm{O}_{2}{ }^{+}$ & 60.0211 & 0.60 \\
\hline
\end{tabular}


4 Table S2. Description of spectra which have higher $f_{C_{5} H_{6} O}$ than background $f_{C_{5} H_{6} O}$, labeled by 5 number in Fig. 5.

\begin{tabular}{|c|c|c|c|}
\hline Index & Spectra name & Description of spectra sources & References \\
\hline 1 & $\begin{array}{l}\text { HOA }^{\mathrm{a}} \text { from CARES } \\
\text { campaign }\end{array}$ & $\begin{array}{l}\text { Isoprene emission influenced, } \\
\text { aerosol is neutralized }\end{array}$ & (Setyan et al., 2012) \\
\hline 2 & OA from CA Central Valley & $\begin{array}{l}\text { Isoprene emission influenced, } \\
\text { aerosol is slightly acidic. }\end{array}$ & (Dunlea et al., 2009) \\
\hline 3 & $\begin{array}{l}\mathrm{NO}_{3}+\Delta \text {-Carene reaction in } \\
\text { Chamber }\end{array}$ & Biogenic SOA & Chamber study in CU \\
\hline 4 & $\begin{array}{l}\text { Ozonolysis a-terpene in } \\
\text { Chamber }\end{array}$ & Biogenic SOA & (Chhabra et al., 2010) \\
\hline 5 & $\mathrm{SV}_{-} \mathrm{OOA}{ }^{\mathrm{b}}$ from SOAR & Slight biogenic influence & (Docherty et al., 2011) \\
\hline 6 & $\begin{array}{l}\text { SV-OOA from Paris } \\
\text { summer campaign }\end{array}$ & $\begin{array}{l}\text { Not mentioned in study, } \\
\text { however, forests around the } \\
\text { sampling site. }\end{array}$ & (Crippa et al., 2013) \\
\hline 7 & $\begin{array}{l}\mathrm{NO}_{3}+\Delta \text {-Carene reaction in } \\
\text { Chamber }\end{array}$ & Biogenic SOA & Chamber study in $\mathrm{CU}$ \\
\hline \multirow[t]{2}{*}{8} & SV-OOA from SOAS & $\begin{array}{l}\text { Isoprene and monoterpene } \\
\text { influenced }\end{array}$ & This study \\
\hline & $\begin{array}{l}\mathrm{NO}_{3}+\Delta \text {-Carene reaction in } \\
\text { Chamber }\end{array}$ & Biogenic SOA & Chamber study in CU \\
\hline 10 & $\begin{array}{l}\text { MO-OOA }{ }^{\mathrm{i}} \text { in CARES } \\
\text { campaign }\end{array}$ & $\begin{array}{l}\text { Urban SOA with isoprene } \\
\text { emission-influenced }\end{array}$ & (Setyan et al., 2012) \\
\hline 11 & SV-OOA in MILAGRO & Urban SOA & $\begin{array}{l}\text { (Aiken et al., } \\
\text { 2009; Ulbrich et al., 2009) }\end{array}$ \\
\hline 12 & LV-OOA in Paris summer & $\begin{array}{l}\text { Urban-background SOA, } \\
\text { forests around the sampling } \\
\text { site. }\end{array}$ & (Crippa et al., 2013) \\
\hline 13 & Adipic acid & Pure chemical OA standards & (Canagaratna et al., 2015) \\
\hline 14 & $\begin{array}{l}\text { 3-Hydroxy-3- } \\
\text { Methylglutaric Acid }\end{array}$ & Pure chemical OA standards & (Canagaratna et al., 2015) \\
\hline 15 & 4-ketopimelic acid & Pure chemical OA standards & (Canagaratna et al., 2015) \\
\hline 16 & 5-Oxoazelaic acid & Pure chemical OA standards & (Canagaratna et al., 2015) \\
\hline 17 & $\begin{array}{l}\text { Gamma ketopimelic acid } \\
\text { dilactone }\end{array}$ & Pure chemical OA standards & (Canagaratna et al., 2015) \\
\hline \multicolumn{4}{|c|}{${ }^{\mathrm{a}} \mathrm{HOA}=$ Hydrocarbon-like OA } \\
\hline \multicolumn{4}{|c|}{${ }^{\mathrm{b}} \mathrm{SV}-\mathrm{OOA}=$ Semi-volatile oxygenated OA } \\
\hline MO- & $A=$ More-oxidized oxyge & & \\
\hline
\end{tabular}



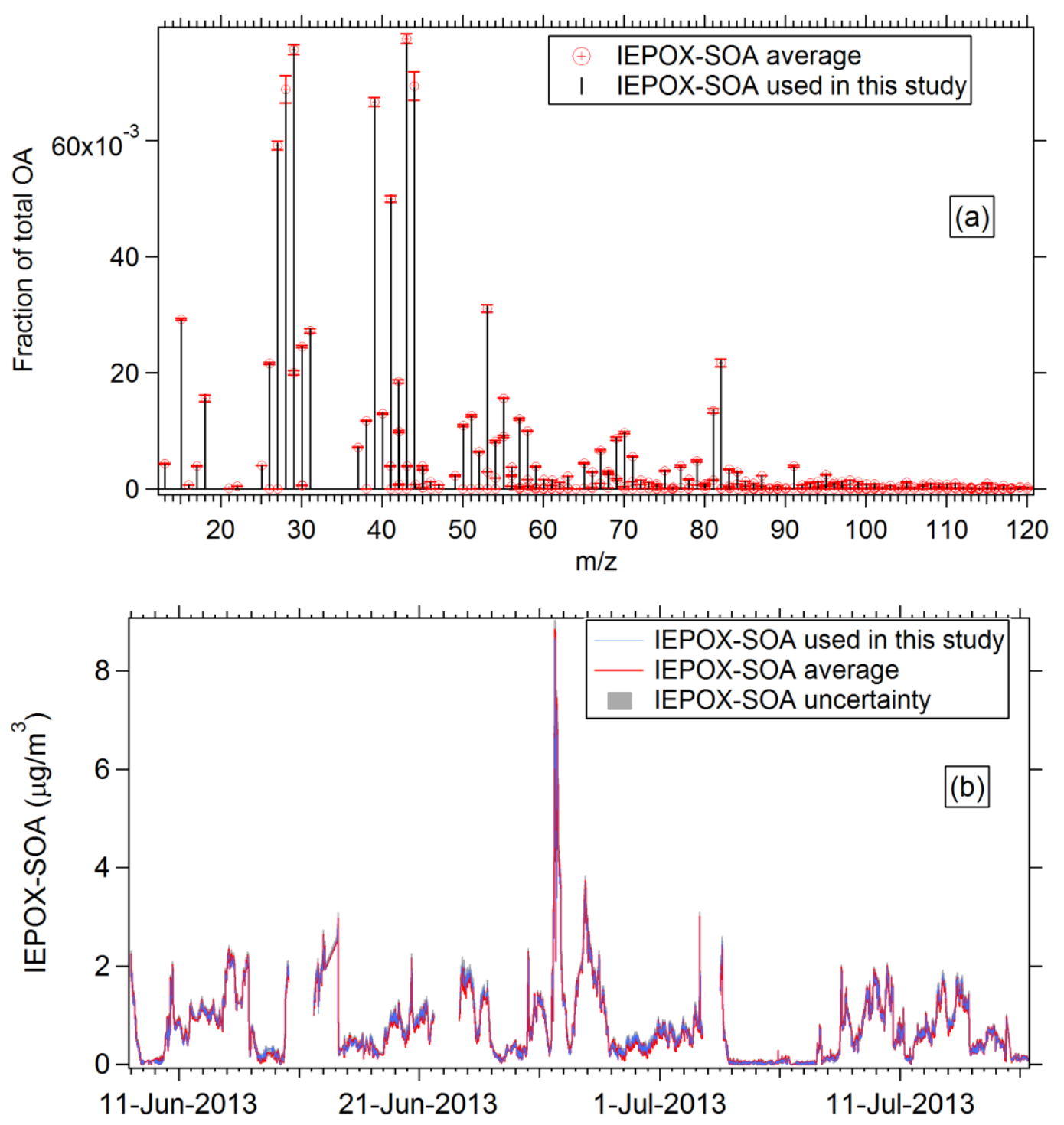

10

11 Figure S1. Results from bootstrapping analysis of the 4-factor solution of the SOAS dataset.

12 Average IEPOX-SOA, with standard deviation, are shown for IEPOX-SOA (a) mass spectrum 13 and (b) time series.

14

15 

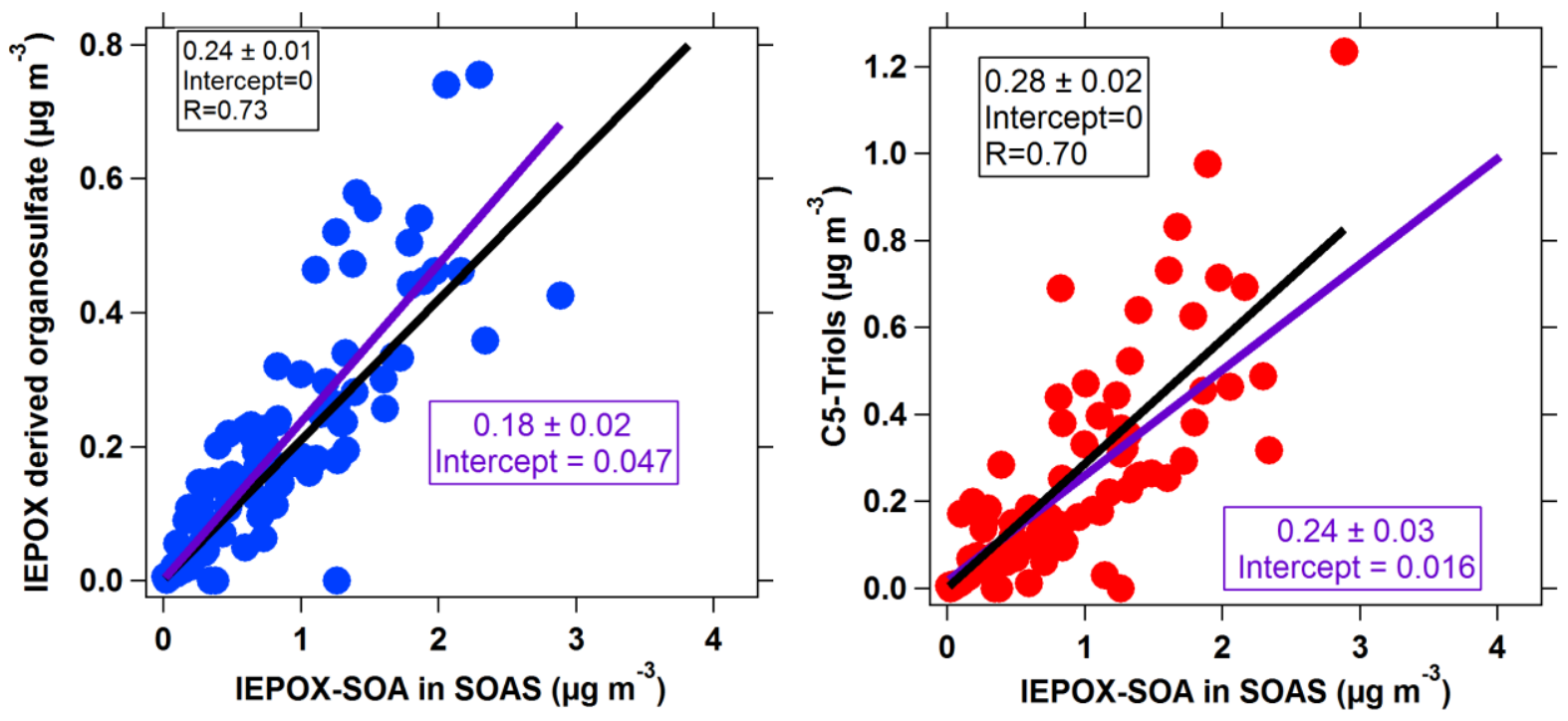

Figure S2. Scatter plots between IEPOX-derived organosulfate and C5-triols vs IEPOX-SOAPMF in the SOAS study. The IEPOX-derived organosulfate and C5-triols were measured in GC/MS and LC/MS analysis of filter extracts (Lin et al., 2014;Budisulistiorini et al., 2015). 

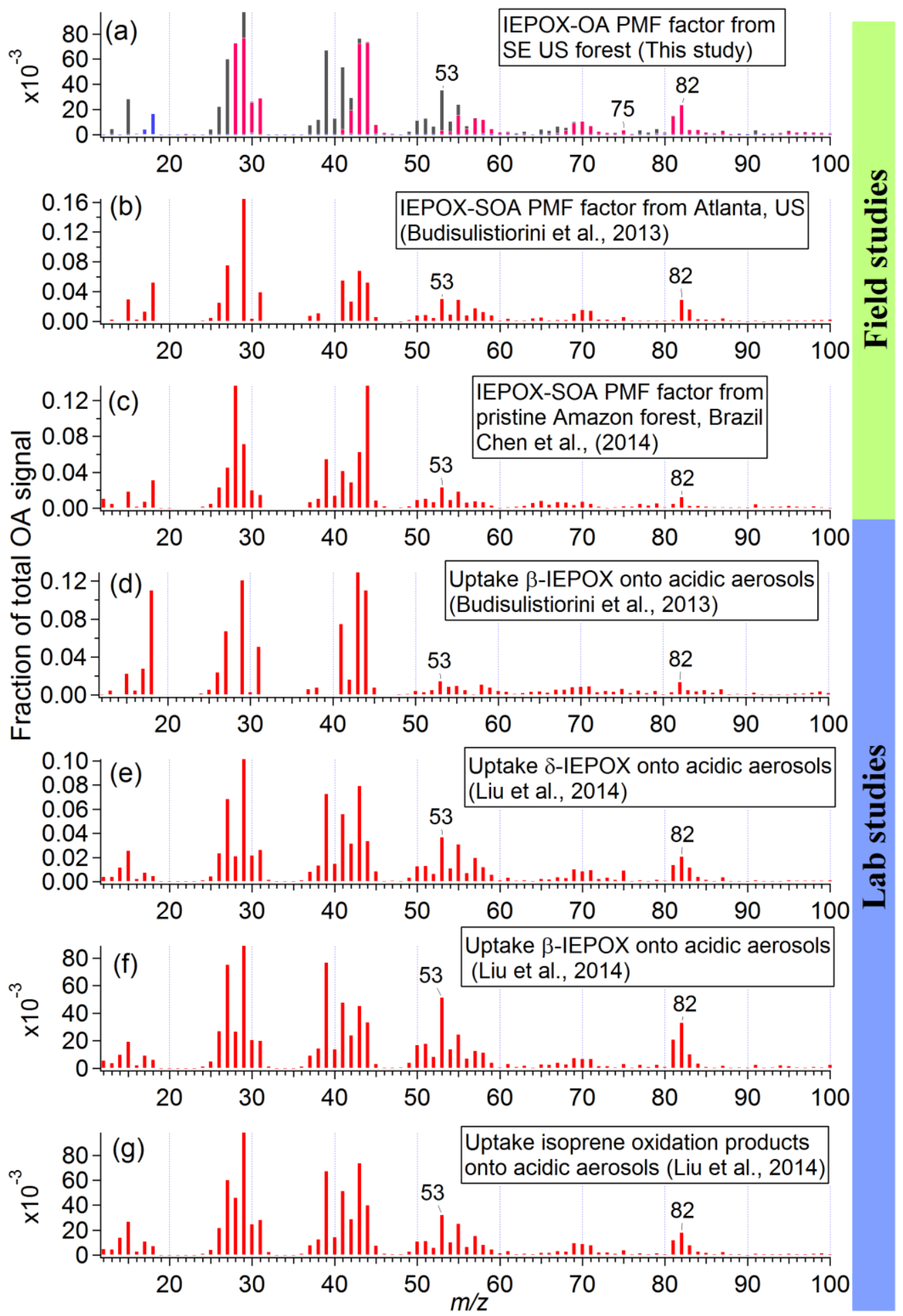

Figure S3. Mass spectra of IEPOX-SOA from different studies. Panel (a) - (c) are the results 24 from field studies. Panel $(\mathrm{d})-(\mathrm{g})$ are the results from lab studies. 

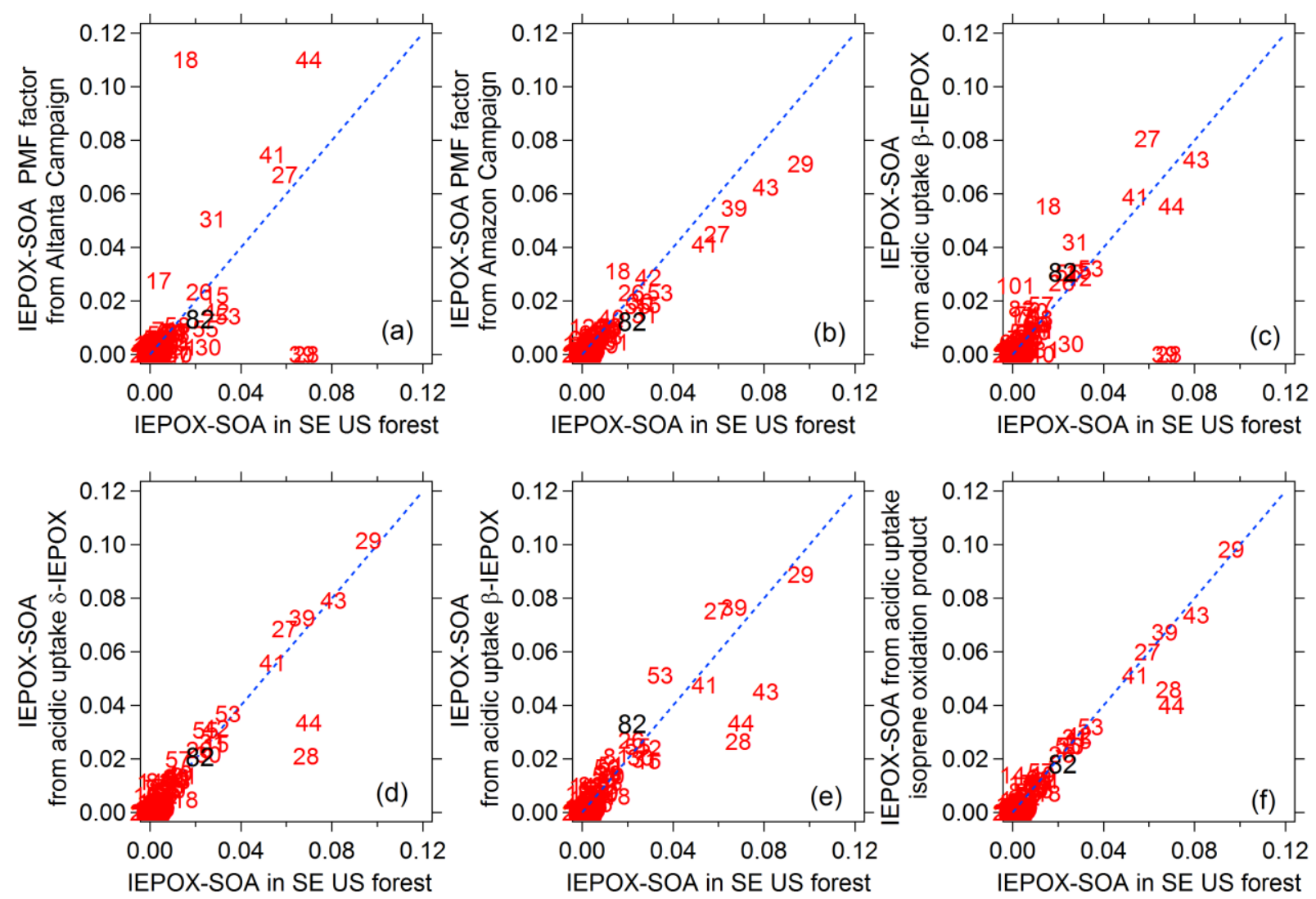

IEPOX-SOA in SE US forest

IEPOX-SOA in SE US forest

28 Figure S4. Scatter plots of IEPOX-SOA spectra in other studies vs IEPOX-SOA spectrum from this study (SOAS, SE US forest). The spectra on the y-axes are in the same order as Figures S1

30 (b) to (g).

31 

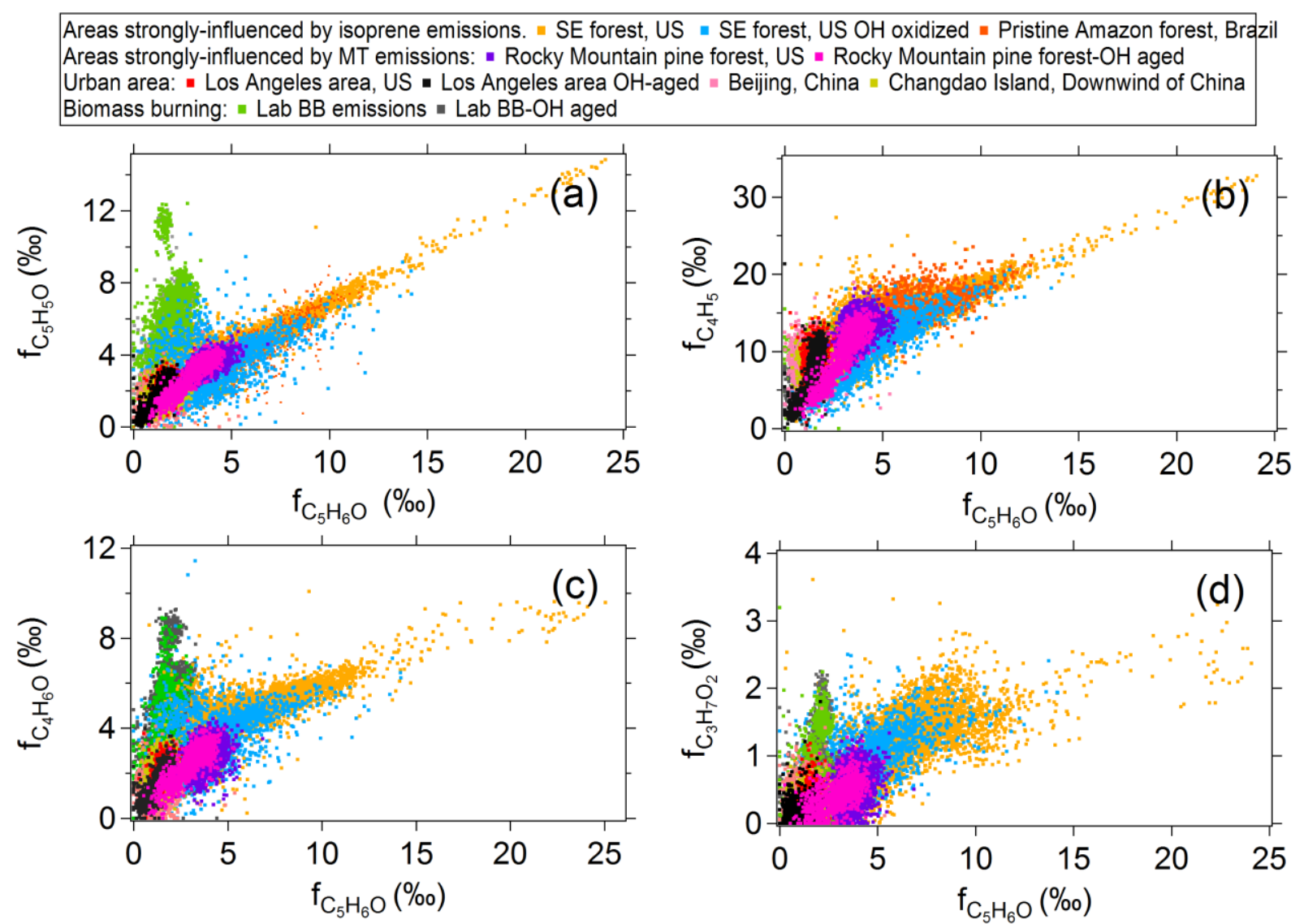

35 Figure S5. Scatter plots of abundance of ions versus $f_{C_{5} H_{6} O}^{O A}$ obtained in different studies: (a)

$36 f_{C_{5} H_{5} O}^{O A}$, (b) $f_{C_{4} H_{5}}^{O A}$, (c) $f_{C_{4} H_{6} O}^{O A}$, and (d) $f_{C_{3} H_{7} O_{2}}^{O A}$. Compared to $f_{C_{5} H_{6} O}^{O A}, f_{C_{4} H_{5}}^{O A}, f_{C_{4} H_{6} O}^{O A}$, and $f_{C_{5} H_{5} O}^{O A}$ have

37 high background levels in urban and biomass-burning emissions. The signal to noise of

$38 f_{C_{3} \mathrm{H}_{7} \mathrm{O}_{2}}^{O A}$ measured in AMS is very low. 
41

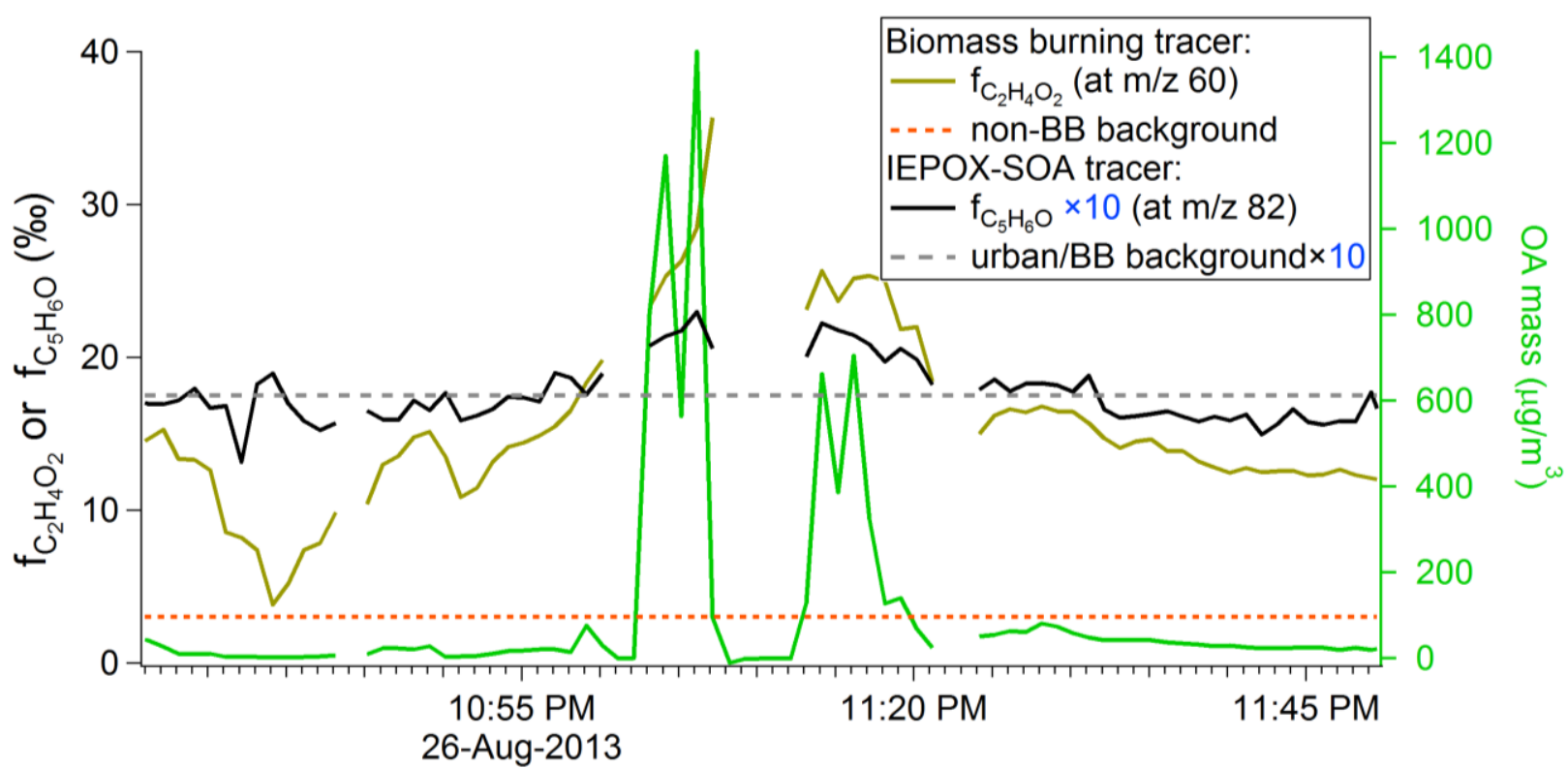

Figure S6. Time series of OA mass concentration, and of tracers for IEPOX-SOA $\left(f_{C_{5} \mathrm{H}_{6} \mathrm{O}}\right)$ and

44 biomass-burning $\left(f_{C_{2} H_{4} O_{2}}, m / z, 60.0211\right)$ compared to their respective backgrounds on the research flight on Aug 26, 2013 during the SEAC4RS campaign. The biomass-burning tracer indicates extensive fire influence during this period, while the IEPOX-SOA tracer stays at background levels across widely varying OA concentrations. 


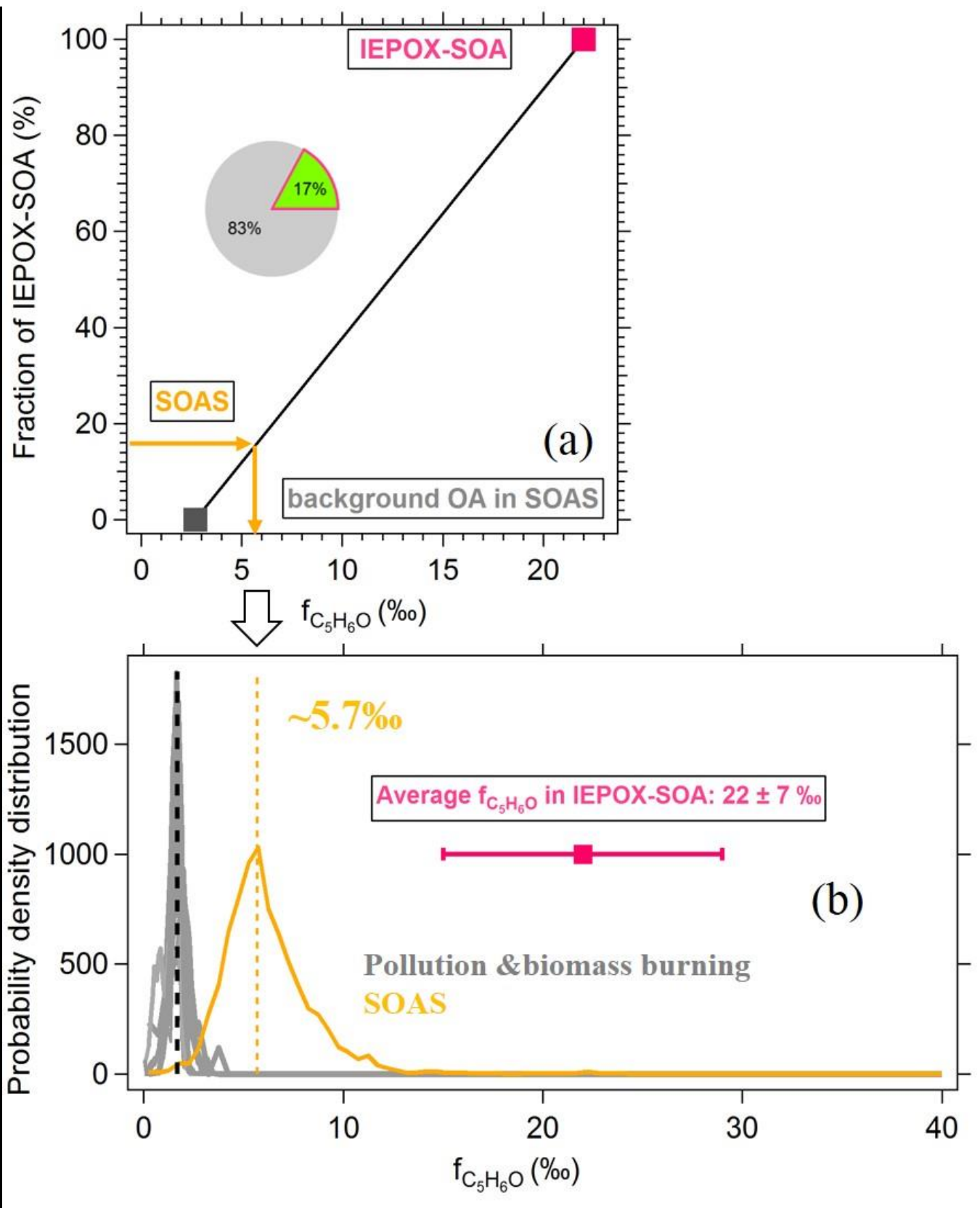

Figure S7. Schematic of the estimation method of IEPOX-SOA based on ambient $f_{C_{5} \mathrm{H}_{6} \mathrm{O}}$. (a) Fraction of IEPOX-SOA in total OA vs ambient $f_{C_{5} H_{6} O}^{O A}$ (b) probability distribution of $f_{C_{5} H_{6} O}^{O A}$ in

52 SOAS and in background studies. The average background of $f_{C_{5} \mathrm{H}_{6} \mathrm{O}}^{O A}$ from SOAS-CTR should be 53 between the $f_{C_{5} \mathrm{H}_{6} \mathrm{O}}$ from urban and biomass burning emissions $(\sim 1.7 \%$ o $)$ and $f_{C_{5} \mathrm{H}_{6} \mathrm{O}}$ strongly 54 influenced by monoterpene emissions, which we can use 3.7\% from Rocky Mountain site as 55 representative value. An average $f_{C_{5} H_{6} O}^{O A}$ value of $2.7 \%$ was used here for the background $f_{C_{5} H_{6} O}^{O A}$ 56 for SOAS-CTR. $f_{C_{5} H_{6} O}$ in IEPOX-SOAPMF is $22 \%$. Two values corresponding to $0 \%$ and $100 \%$ 57 IEPOX-SOA in total OA, are shown as two square points shown in Fig. S5a. If we assume the 58 air containing these two types of OA are mixed with each other, then we can draw a line between 
59 these two points in Fig. S5a. Ambient $f_{C_{5} H_{6} O}^{O A}$ partially contributed by IEPOX-SOA should vary 60 along this line. Take SOAS as an example, 17\% of OA in SOAS was composed by IEPOX-SOA, 61 then it corresponds to an expected average $f_{C_{5} H_{6} O}^{O A}$ of $\sim 5.7 \%$, which is consistent with what was 62 observed (Fig. S5b). The peak of the probability distribution of $f_{C_{5} H_{6} O}^{O A}$ in SOAS is around 5.7\%. 63 64 


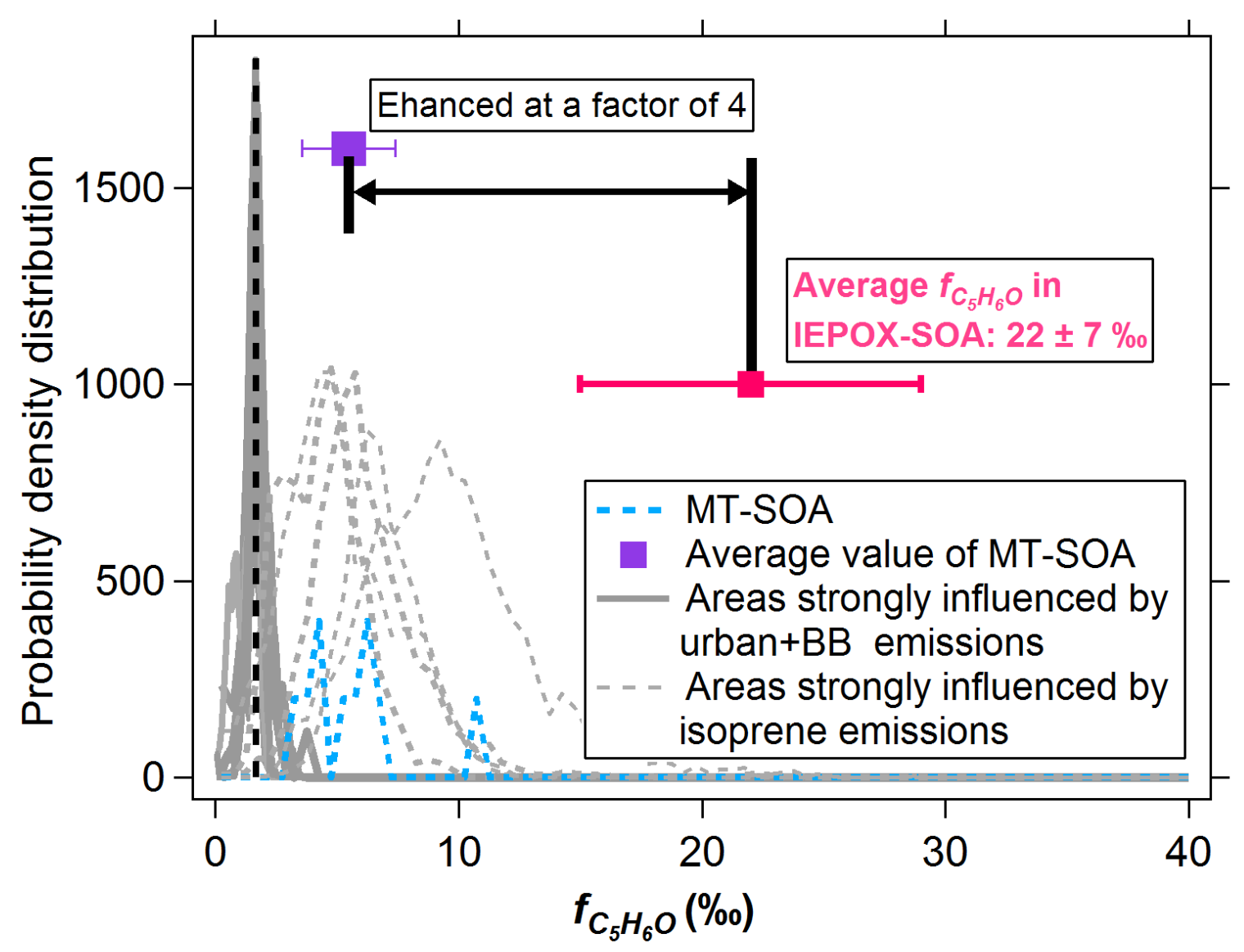

65

66 Figure S8 Comparison between $f_{C_{5} H_{6} O}^{M T-S O A}$ and $f_{C_{5} H_{6} O}^{I E P O X O A}, f_{C_{5} H_{6} O}^{O A}$ from areas strongly

67 influenced by urban + biomass burning and isoprene emissions are also shown.

68 


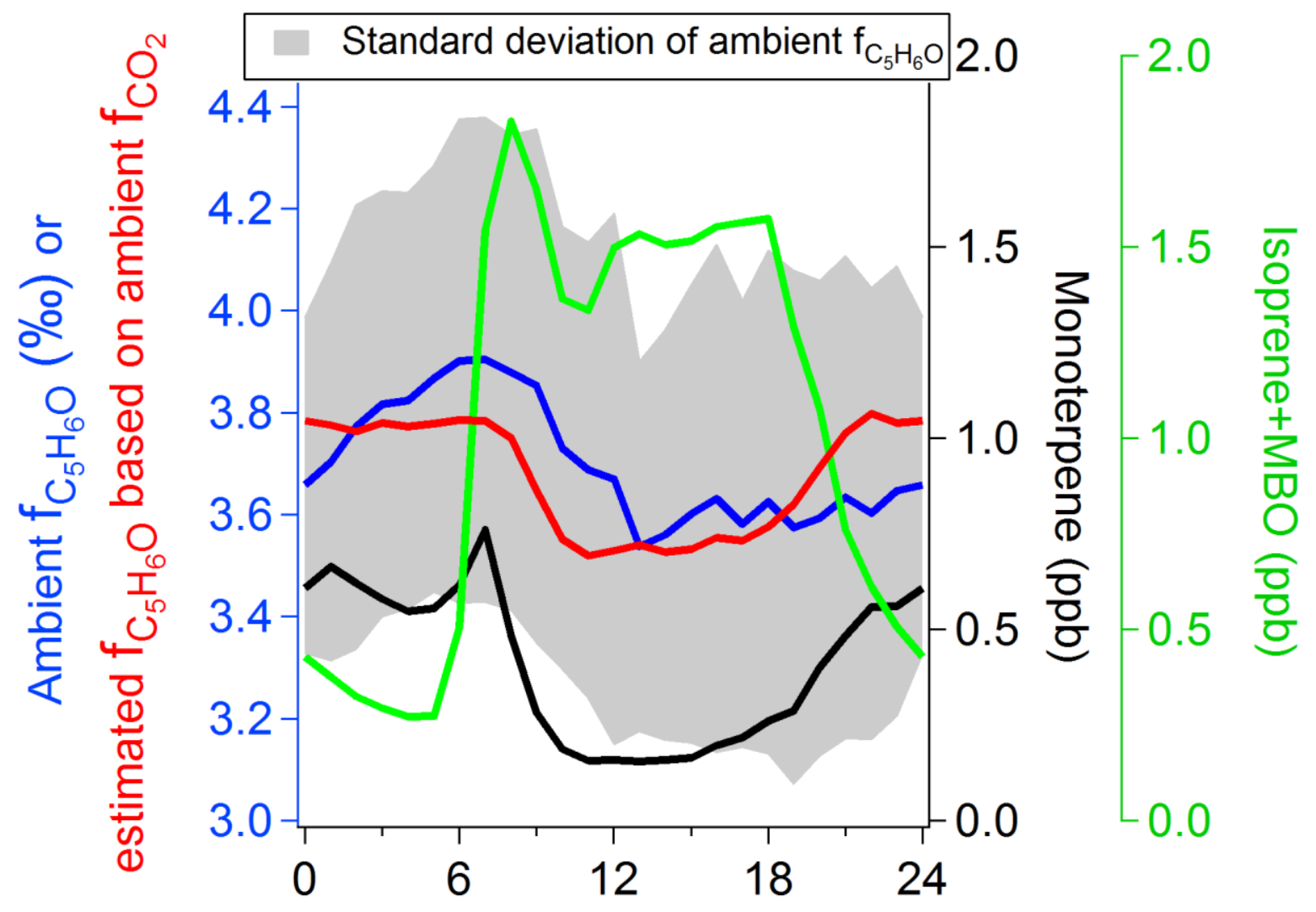

70 Figure S9. Diurnal variation of ambient $f_{C_{5} \mathrm{H}_{6} \mathrm{O}}^{O A}$ at the Manitou Forest pine forest site in the

71 Rocky Mountains during the BEACHON-RoMBAS 2011 field study, together with diurnal

72 variations of estimated $f_{C_{5} \mathrm{H}_{6} \mathrm{O}}^{\mathrm{OA}}$ from $f_{\mathrm{CO}_{2}}^{O A}$ based on regression results between $f_{\mathrm{C}_{5} \mathrm{H}_{6} \mathrm{O}}^{O A}$ and $f_{\mathrm{CO}_{2}}^{O A}$

73 (ambient+Oxidation flow reactor) in this study. The diurnal variation of monoterpene and

74 isoprene+MBO are also shown. 


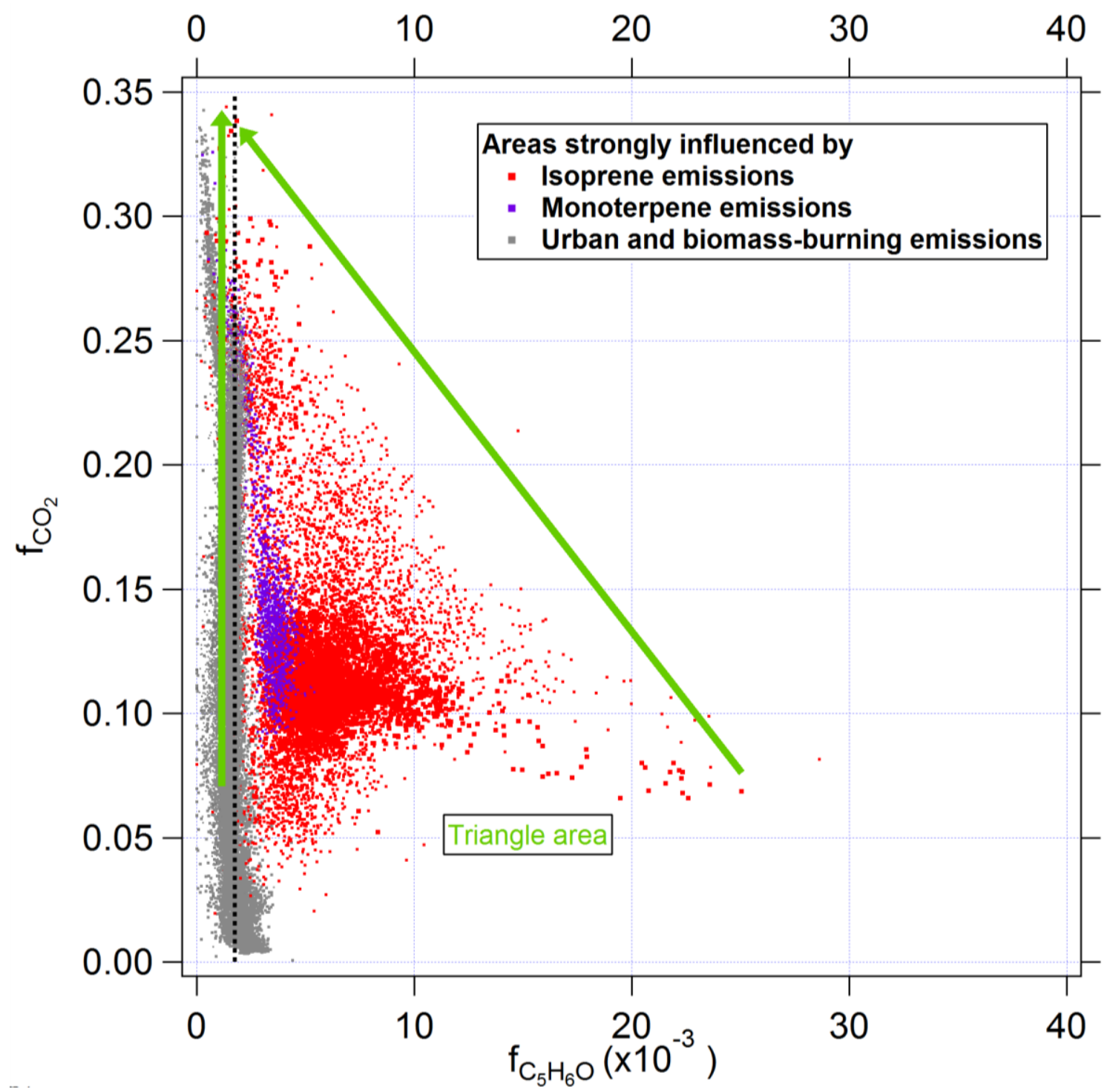

80 Figure S10. Scatter plot between $f_{\mathrm{CO}_{2}}^{O A}$ and $f_{C_{5} \mathrm{H}_{6} \mathrm{O}}^{O A}$ for all the ambient OA dataset. Green arrows 81 are added to guide the eye.

82.

83

84

85 


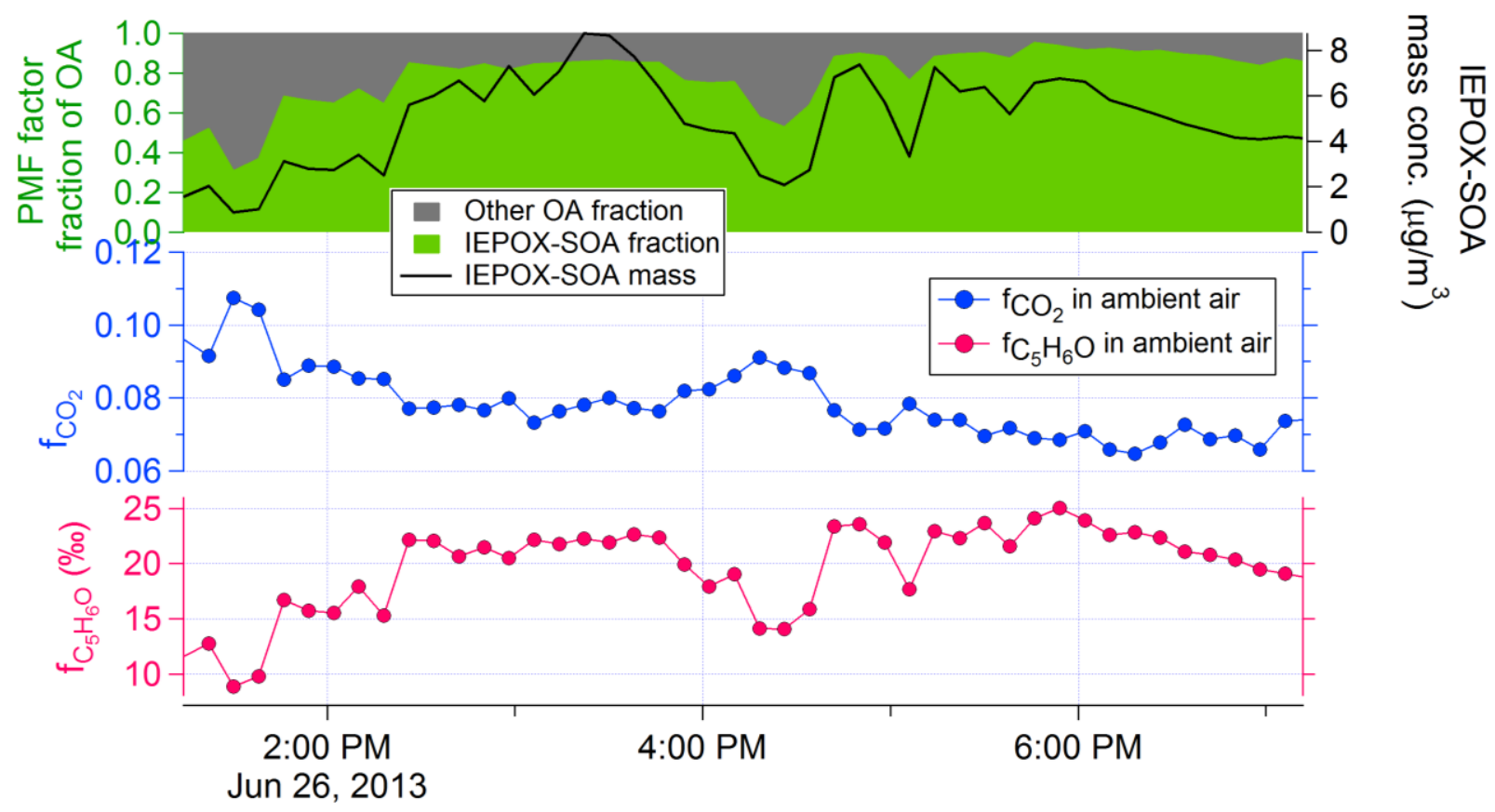

87 Figure S11. Time series of ambient $f_{C_{5} \mathrm{H}_{6} \mathrm{O}}^{\mathrm{OA}_{1}} f_{\mathrm{CO}_{2}}^{\mathrm{OA}}$, and IEPOX-SOA mass concentrations, together 88 with the IEPOX-SOA fraction of OA during the SOAS-CTR campaign in a SE US forest. During 89 this period, high sulfate and IEPOX-SOA mass concentrations and mass fractions are observed. 


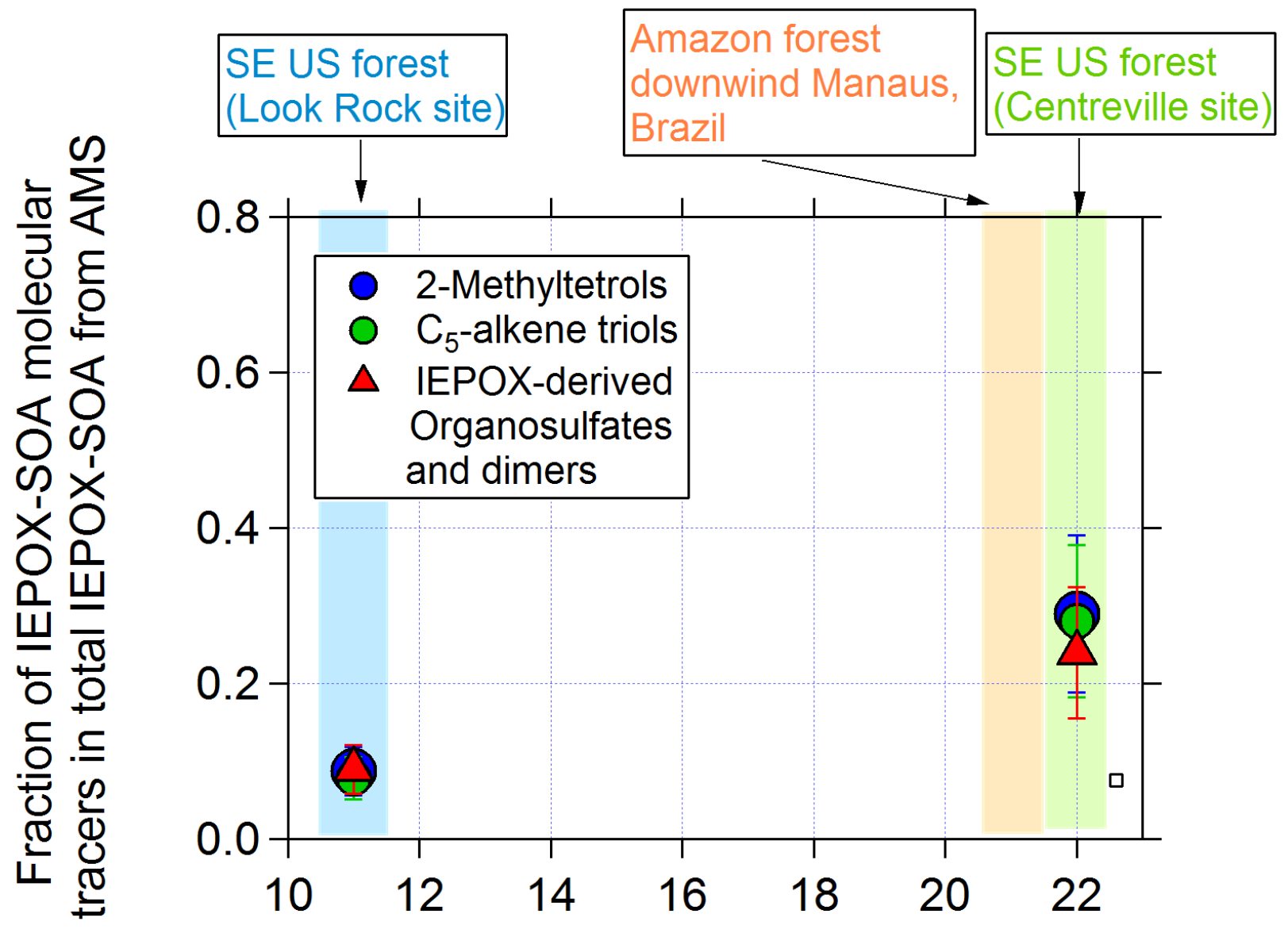

93 Figure S12 Scatter plot between different IEPOX-SOA molecular tracers (Methyltetrol, C5-

94 alkene triols and IEPOX-derived organosulfates and their dimers) vs IEPOX-SOAPMF and $f_{82}$ in 95 IEPOX-SOA 
Estimated IEPOX-SOA in AMAZE-08 (Amazon forest) by substracting OA background from regions strongly impacted by:

(A) Urban+BB emissons

(B) MT emissions
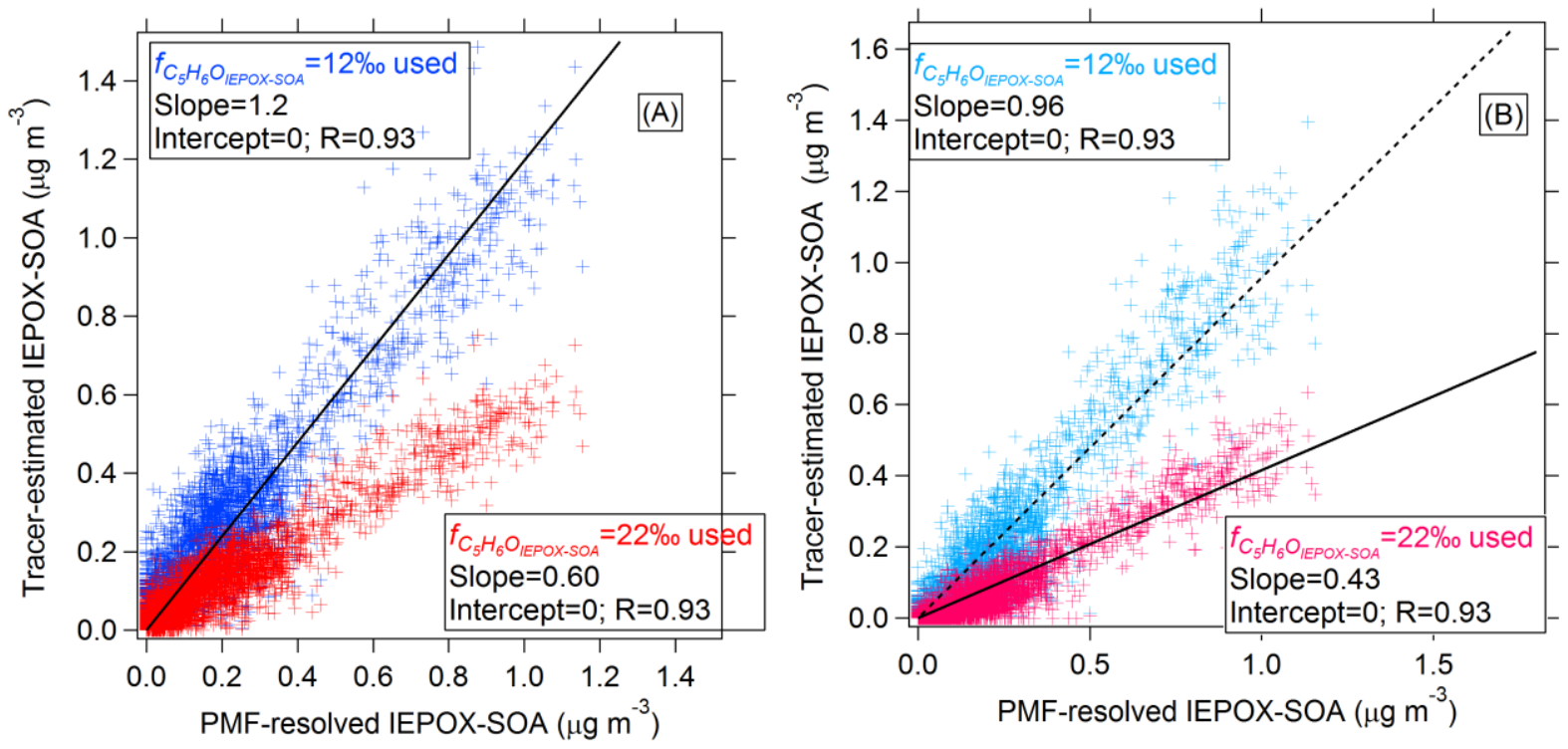

99 Figure S13. Scatter plot between tracer-estimated IEPOX-SOA and IEPOX-SOAPMF at a pristine

100 Amazon forest site (AMAZE-08). The tracer-based IEPOX-SOA was estimated using OA

101 background from regions strongly influenced by (A) urban and biomass-burning emissions and

102 (B) monoterpene emissions. In each plot, we used two $f_{C_{5} \mathrm{H}_{6} \mathrm{O}}^{I I P O A}$, from the average IEPOX-

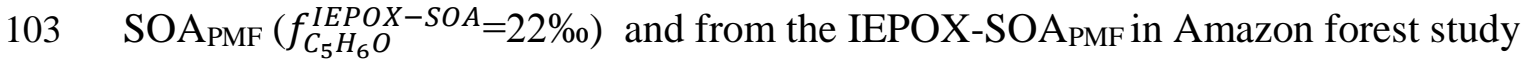

$104 \quad\left(f_{C_{5} \mathrm{H}_{6} \mathrm{O}}^{\mathrm{IEPOX}-S O A}=12 \%\right)$.

105

106

107

108 


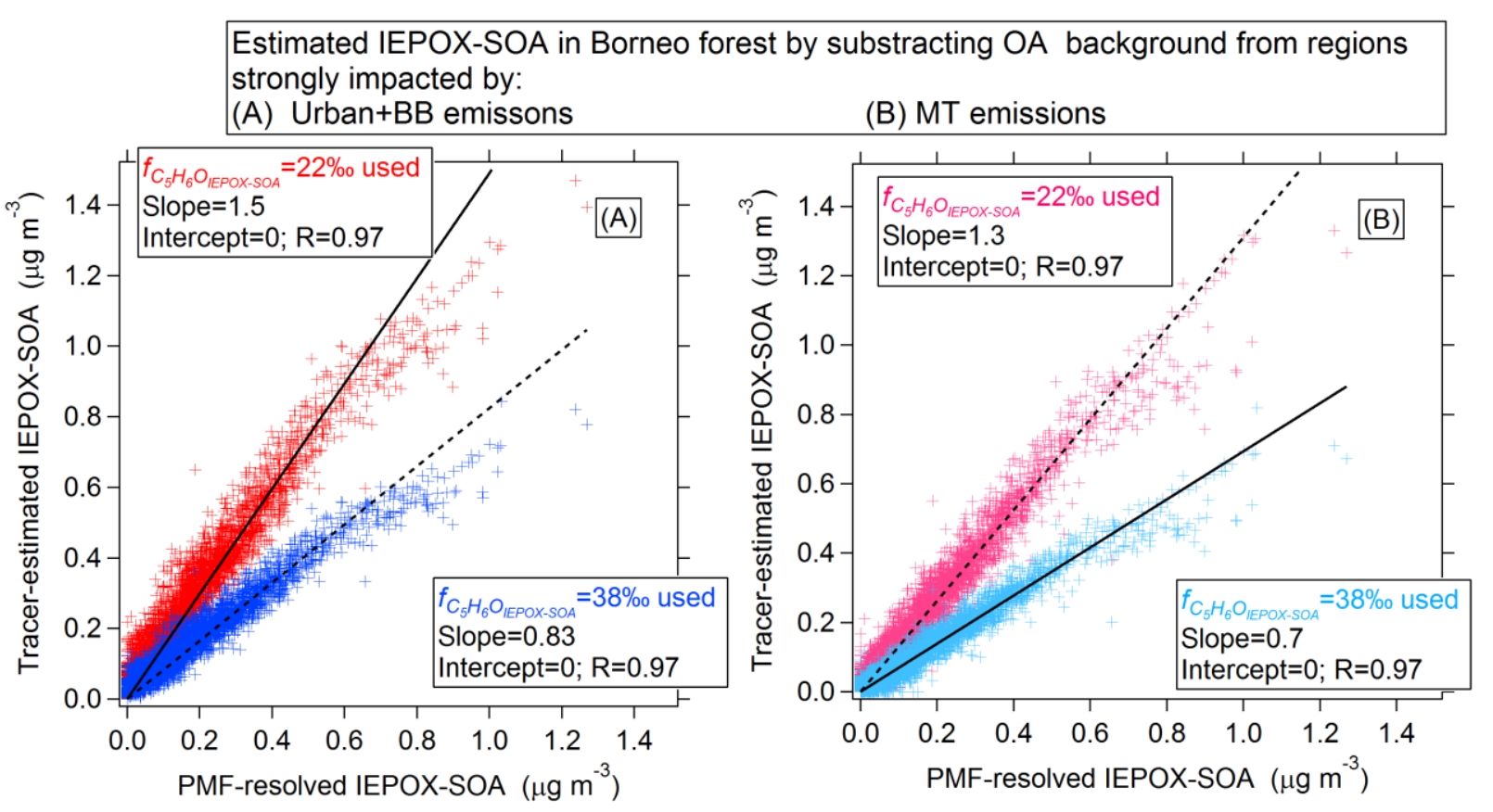

109

110 Figure S14 Scatter plot between estimated IEPOX-SOA and IEPOX-SOAPMF at a Borneo forest

111 site. The tracer-based IEPOX-SOA was estimated using OA background from regions strongly

112 influenced by (A) urban and biomass-burning emissions and (B) monoterpene emissions. In each

113 plot, we used two $f_{C_{5} \mathrm{H}_{6} O}^{I E P O X}-S O A$, from the average IEPOX-SOAPMF $\left(f_{C_{5} \mathrm{H}_{6} O}^{I E P O X-S O A}=22 \%\right)$ and from

114 the IEPOX-SOAPMF in Borneo forest study $\left(f_{C_{5} H_{6} O}^{I E P O X}-S O A=38 \%\right.$ ). 


\subsection{Bounds for using the IEPOX-SOA estimation method}

In theory, our method can easily produce an estimate of "IEPOX-SOA" from an AMS dataset, but the errors could be substantial in some cases. The guidelines below are meant to limit the errors when applying this method:

1) We first recommend making the scatter plot of $f_{\mathrm{CO}_{2}}^{O A}$ and $f_{\mathrm{C}_{5} \mathrm{H}_{6} \mathrm{O}}$ and then compare it to Fig. 5 in this study to help evaluate the possible presence of IEPOX-SOA.

2) For datasets where an important influence of MT-SOA is suspected: if all the $f_{C_{5} H_{6} O}^{O A}$ in total OA are $\sim 3.1 \%$ or lower within measurement noise, the estimated IEPOX-SOA will show negative and positive values scattered around zero, indicating negligible IEPOXSOA in the dataset. A similar conclusion can be reached for urban or BB-dominated locations when $f_{C_{5} \mathrm{H}_{6} \mathrm{O}} \sim 1.7 \%$ or lower for most data points.

3) When the scatter plot between $f_{\mathrm{CO}_{2}}^{O A}$ and $f_{C_{5} \mathrm{H}_{6} \mathrm{O}}^{O A}$ shows obvious enhanced $f_{C_{5} \mathrm{H}_{6} \mathrm{O}}^{O A}$ above the most-relevant background value, users can easily use the tracer-based method to estimate the IEPOX-SOA mass concentration. If the source of the background OA is not known, we suggest using both background corrections and reporting the range of results.

4) Cases intermediate between No. 2 and 3 above, i.e. when $f_{C_{5} H_{6} O}^{O A}$ is only slightly above the relevant background level will have the largest relative uncertainty. In this case we recommend applying the method and evaluating the results carefully, as exemplified for the Rocky Mountain dataset in this paper (section 3.5). E.g. diurnal variations of $f_{C_{5} H_{6} O}^{O A}$ and SOA precursors (e.g., isoprene and monoterpene), together with diurnal variation of estimated IEPOX-SOA, provide useful indicators about whether the results are meaningful. For cases in which the fraction of IEPOX-SOA in total OA is relatively low (e.g., $<5 \%$ ) and the fraction of MT-SOA in total OA is high (e.g., >50\%), the uncertainty of the IEPOX-SOA estimate will be very high. For this type of situation the full PMF method may be required.

Besides ease of use, another advantage of the tracer-based estimation method is that it can be used to quantify IEPOX-SOA based on brief periods of elevated concentrations, e.g. as often encountered in aircraft studies. In those cases it may be difficult for PMF to resolve an IEPOXSOA factor, but no such limitation applies to this estimation method.

\subsection{Uncertainties of IEPOX-SOA estimation method.}

To estimate the accuracy of our IEPOX-SOA tracer-based estimation method, we used this method to estimate IEPOX-SOA from another two ambient datasets with the lowest and highest $f_{C_{5} \mathrm{H}_{6} \mathrm{O}}^{\mathrm{IEPOX}-S O A}$ in PMF-resolved IEPOX-SOA (IEPOX-SOAPMF) among all the studies in this paper. The lowest value is from a dataset in the pristine Amazon forest (AMAZE-08) where $f_{C_{5} \mathrm{H}_{6} \mathrm{OX}}^{I E S O A}=12 \%$ (Chen et al., 2015) and the highest value from a dataset in a Borneo forest with $f_{C_{5} H_{6} O}^{I E P O X}-S O A=38 \%$ (Robinson et al., 2011). Since the $f_{C_{5} H_{6} O}^{I E P O X-S O A}$ values in these two datasets are the two farthest from the average $f_{C_{5} \mathrm{H}_{6} \mathrm{O}}^{\mathrm{IEPOX}-S O A}(22 \pm 7 \%$ ), the estimation method 
153 results from these two datasets represent the worst case scenarios for all datasets published so 154 far.

155 The estimation results from both datasets are shown in Fig. S13 and Fig. S14. Both of the 156 background $\mathrm{OA}$ corrections for areas strongly influenced by urban+BB emissions and by 157 monoterpene emissions are used.

158 Overall, all variants of the estimated IEPOX-SOA correlate well with IEPOX-SOAPMF (all $159 \mathrm{R}>=0.93)$. When average $f_{C_{5} H_{6} \mathrm{O}}^{I E P O X O A}=22 \%$ is used, the slope between estimated IEPOX-SOA 160 vs IEPOX-SOAPMF is between 0.43-1.5, i.e. within a factor of 2.2. When the actual $f_{C_{5} \mathrm{H}_{6} \mathrm{O}-S O A_{\text {in }}}^{I \mathrm{O} O X}$ 161 each dataset is used, the slope between estimated IEPOX-SOA vs IEPOX-SOAPMF is in a range 162 of $0.7-1.2$, i.e. within $30 \%$.

163

164

165 


\section{References}

Aiken, A. C., Salcedo, D., Cubison, M. J., Huffman, J. A., DeCarlo, P. F., Ulbrich, I. M., Docherty, K. S., Sueper, D., Kimmel, J. R., Worsnop, D. R., Trimborn, A., Northway, M., Stone, E. A., Schauer, J. J., Volkamer, R. M., Fortner, E., de Foy, B., Wang, J., Laskin, A., Shutthanandan, V., Zheng, J., Zhang, R., Gaffney, J., Marley, N. A., ParedesMiranda, G., Arnott, W. P., Molina, L. T., Sosa, G., and Jimenez, J. L.: Mexico City aerosol analysis during MILAGRO using high resolution aerosol mass spectrometry at the urban supersite (T0) - Part 1: Fine particle composition and organic source apportionment, Atmos Chem Phys, 9, 6633-6653, 2009.

Canagaratna, M. R., Jimenez, J. L., Kroll, J. H., Chen, Q., Kessler, S. H., Massoli, P., Hildebrandt Ruiz, L., Fortner, E., Williams, L. R., Wilson, K. R., Surratt, J. D., Donahue, N. M., Jayne, J. T., and Worsnop, D. R.: Elemental ratio measurements of organic compounds using aerosol mass spectrometry: characterization, improved calibration, and implications, Atmos. Chem. Phys., 15, 253-272, 10.5194/acp-15-253-2015, 2015.

Chen, Q., Farmer, D. K., Rizzo, L. V., Pauliquevis, T., Kuwata, M., Karl, T. G., Guenther, A., Allan, J. D., Coe, H., Andreae, M. O., Pöschl, U., Jimenez, J. L., Artaxo, P., and Martin, S. T.: Submicron particle mass concentrations and sources in the Amazonian wet season (AMAZE-08), Atmos. Chem. Phys., 15, 3687-3701, 10.5194/acp-15-3687-2015, 2015.

Chhabra, P. S., Flagan, R. C., and Seinfeld, J. H.: Elemental analysis of chamber organic aerosol using an aerodyne high-resolution aerosol mass spectrometer, Atmos. Chem. Phys., 10, 4111-4131, 10.5194/acp-10-4111-2010, 2010.

Crippa, M., El Haddad, I., Slowik, J. G., DeCarlo, P. F., Mohr, C., Heringa, M. F., Chirico, R., Marchand, N., Sciare, J., Baltensperger, U., and Prévôt, A. S. H.: Identification of marine and continental aerosol sources in Paris using high resolution aerosol mass spectrometry, Journal of Geophysical Research: Atmospheres, 118, 1950-1963, doi: 10.1002/jgrd.50151, 2013.

Docherty, K. S., Aiken, A. C., Huffman, J. A., Ulbrich, I. M., DeCarlo, P. F., Sueper, D., Worsnop, D. R., Snyder, D. C., Peltier, R. E., Weber, R. J., Grover, B. D., Eatough, D. J., Williams, B. J., Goldstein, A. H., Ziemann, P. J., and Jimenez, J. L.: The 2005 Study of Organic Aerosols at Riverside (SOAR-1): instrumental intercomparisons and fine particle composition, Atmos. Chem. Phys., 11, 12387-12420, 10.5194/acp-11-12387-2011, 2011.

Dunlea, E. J., DeCarlo, P. F., Aiken, A. C., Kimmel, J. R., Peltier, R. E., Weber, R. J., Tomlinson, J., Collins, D. R., Shinozuka, Y., McNaughton, C. S., Howell, S. G., Clarke, A. D., Emmons, L. K., Apel, E. C., Pfister, G. G., van Donkelaar, A., Martin, R. V., Millet, D. B., Heald, C. L., and Jimenez, J. L.: Evolution of Asian aerosols during transpacific transport in INTEX-B, Atmos Chem Phys, 9, 7257-7287, 2009.

Robinson, N. H., Hamilton, J. F., Allan, J. D., Langford, B., Oram, D. E., Chen, Q., Docherty, K., Farmer, D. K., Jimenez, J. L., Ward, M. W., Hewitt, C. N., Barley, M. H., Jenkin, M. E., Rickard, A. R., Martin, S. T., McFiggans, G., and Coe, H.: Evidence for a significant proportion of Secondary Organic Aerosol from isoprene above a maritime tropical forest, Atmos. Chem. Phys., 11, 1039-1050, 10.5194/acp-11-1039-2011, 2011.

Setyan, A., Zhang, Q., Merkel, M., Knighton, W. B., Sun, Y., Song, C., Shilling, J. E., Onasch, T. B., Herndon, S. C., Worsnop, D. R., Fast, J. D., Zaveri, R. A., Berg, L. K., Wiedensohler, A., Flowers, B. A., Dubey, M. K., and Subramanian, R.: Characterization of submicron particles influenced by mixed biogenic and anthropogenic emissions using 
high-resolution aerosol mass spectrometry: results from CARES, Atmos. Chem. Phys., 12, 8131-8156, 10.5194/acp-12-8131-2012, 2012.

Ulbrich, I. M., Canagaratna, M. R., Zhang, Q., Worsnop, D. R., and Jimenez, J. L.: Interpretation of organic components from Positive Matrix Factorization of aerosol mass spectrometric data, Atmos Chem Phys, 9, 2891-2918, 2009.

216

217 